UDC $377: 33$

\title{
Features of using of innovative pedagogical technologies during the training of economic specialties students
}

\author{
Duba N.* \\ Svitlovodsk Polytechnic College of the Central National Technical University, Svitlovodsk, Ukraine
}

Received: 10.03 .2019

Accepted: 28.12 .2019

\begin{abstract}
Development of methods of formation of professional competence of students of economic specialties by means of innovative technologies. The analysis of the modern process of preparation of specialists of different specialties is carried out. Prospects of development of the education system of Ukraine with the use of innovative technologies are noted. It is determined that one of the modern methods of increasing the acquisition of knowledge is the use of innovative technologies as a means of presenting educational material. Also, pedagogical technology reflects the tactics of pedagogical technologies implementation and is based on the knowledge of the laws of functioning of the system "teacher - environment - student". Theoretical, methodological and organizational aspects of teaching economic disciplines are considered. The role of innovative approaches and active methods of teaching economic disciplines in shaping future specialists' readiness for professional activity, their economic thinking and economic behavior is highlighted. Examples of the use of modern innovative technologies during lectures for students of economic specialties are given. Acquired skills will help young people to think creatively, to be able to independently find the answers to the necessary questions, to organize and summarize the material, working with educational literature and modern computer technologies. The necessity of using interactive methods of teaching economic subjects for students is substantiated. The methods of interactive learning and their methodical forms, which are the most optimal for the formation of professional competence of students of economic specialties, are considered. As a result of research, it was found that the use of active methods in the learning activities of embedded innovative learning technologies will improve the quality of training of students. This will allow the formation of a new generation of specialists, which is designed to effectively modernize the modern model of the national economy.

Key words: innovative teaching methods, economic knowledge, pedagogical innovations, interactive teaching methods, learning activation tools.
\end{abstract}

\section{Особливості використання інноваційних педагогічних технологій під час навчання студентів економічних спеціальностей}

Дуба Н. П.

Світловодський політехнічний коледж Центральноукраїнського національного технічного університету, Світловодськ, Україна

\begin{abstract}
Анотація. Виконано аналіз стану сучасного процесу підготовки фахівців різних спеціальностей. Означено перспективи розвитку української системи освіти з застосуванням інноваційних технології. Визначено що одним із сучасних методів підвищення засвоєння знань $€$ використання інноваційних технологій як засобу подання навчального матеріалу. Також педагогічна технологія відображає тактику реалізації педагогічних технологій і будується на знанні закономірностей функціонування системи «педагог - середовище студент». Розглянуто теоретичні, методичні та організаційні аспекти викладання економічних дисциплін. 3'ясовано роль інноваційних підходів та активних методів навчання економічних дисциплін у формуванні готовності майбутніх фрахівців до профресійної діяльності, їх економічного мислення та економічної поведінки. Наведено приклади використовувати сучасні інноваційні технології під час проведення лекційних занять для студентів економічних спеціальностей, які сприятимуть творчому мисленню молоді, вмінню самостійно знаходити відповіді на необхідні питання, систематизувати і узагальнювати матеріал, працюючи з навчальною літературою та сучасними комп'ютерними технологіями. Обґрунтовано необхідність використання інтерактивних методів викладання економічних дисциплін для студентів. Розглянуто методи інтерактивного
\end{abstract}

\footnotetext{
Corresponding Author: Duba Nina Pavlivna. E-mail: nina_duba@ukr.net

Svitlovodsk Polytechnic College of the Central National Technical University,

vul. Horodotska, 15, Svitlovodsk, Ukraine, 27501.

Відповідальний автор: Дуба Ніна Павлівна. E-mail: nina_duba@ukr.net

Світловодський політехнічний коледж Центральноукраїнського національного технічного університету. вул. Городоцька, 15, м. Світловодськ, Україна, 27501.
} 
навчання та їх організаційно-методичні форми, які $€$ найбільш оптимальними для фрормування професійної компетентності студентів економічних спеціальностей. Визначено, що використання активних методів навчально-пізнавальної діяльності вбудованих інноваційних технологій навчання дозволить підвищити якість підготовки студентів, сформувати нову генерацію фахівців, які покликані ефективно провести модернізацію сучасної моделі національної економіки.

Ключові слова: інноваційні методи викладання, економічні знання, педагогічні інновації, інтерактивні ме-тоди навчання, засоби активізації навчання.

\title{
Особенности использования инновационных педагогических технологий при обучении студентов экономических специальностей
}

\author{
Дуба Н. П.
}

Светловодский политехнический колледж Центрально национального технического университета, Светловодск, Украина

\begin{abstract}
Аннотация. Выполнен анализ современного процесса подготовки специалистов разных специальностей. Отмечены перспективы развития украинской системы образования с применением инновационной технологии. Определено, что одним из современных методов повышение усвоения знаний является использование инновационных технологий как средства представление учебного материала. Также педагогическая технология отражает тактику реализации педагогических технологий и строится на знании закономерностей функционирования системы «педагог - среда - студент». Рассмотрены теоретические, методические и организационные аспекты преподавания экономических дисциплин. Выяснена роль инновационных подходов и активных методов обучения экономическим дисциплинам в формировании готовности будущих специалистов к профессиональной деятельности, их экономического мышления и экономического поведения. Приведены примеры использовать современных инновационных технологии во время проведения лекционного занятия для студентов экономических специальностей, которые буду способствовать творческому мышление молодежи, умению самостоятельно находить ответы на необходимые вопросы, систематизировать и обобщать материал, работая с учебной литературой и современными компьютерными технологиями. Обоснована необходимость использование интерактивный методов преподавания экономических дисциплин для студентов. Рассмотрены методы интерактивного обучения и их организационно-методические фрормы, которые являются наиболее оптимальными для формирование профессиональной компетентности студентов экономических специальностей. В результате исследований определили, что использование активных методов учебно-познавательной деятельности встроенных инновационных технологий обучения позволить повысить качество подготовки студентов, ссрормировать новое поколение специалистов, которые призваны эфффективного провести модернизацию современной модели национальной экономики.
\end{abstract}

Ключевые слова: инновационные методы преподавания, экономические знания, педагогические инновации, интерактивный методы обучения, средства активизации обучения.

\section{Bcmyn}

На сьогоднішній день інноваційні технології (IT) охоплюють усі сфрери нашого життя. Ми зустрічаємось із застосуванням IT коли спілкуємось, робимо покупки, навчаємось.

Динаміка освітніх подій останнього десятиліття дала поштовх значним удосконаленням в українській системі освіти. Першим витком стало спрямування процесу підготовки фахівців різних спеціальностей на формування в них ключових компетентностей. Витоком другого витку являється створення Національного агентства із забезпечення якості вищої освіти і висунення ним нових критеріїв оцінювання якості освіти. Аналіз цих критеріїв показує, що застосування інноваційних технологій стає нагальною потребою. IT стають необхідним засобом для створення високоякісної, конкурентоспроможної освіти, здатної забезпечити підготовку кваліфікованих спеціалістів.

Особливості застосування IT при підготовці різноманітних видів фрахівців турбують освітян всього світу [1-7]. По-перше IT дозволяють покращити якість навчального процесу. По-друге саме застосування IT потребує динамічного вивчення, оскільки технології постійно оновлюються.

Згідно 3 [8] інноваційні технології - це цілеспрямований системний набір прийомів, засобів організації навчальної діяльності, що охоплює весь процес навчання від визначення мети до одержання результатів. Відповідно хмарне представлення сутності інноваційних технологій в освіті наведене на рис. 1. Педагогічні інноваційні технології змінюють та вдосконалюють функціональні зв'язки системи «педагог-середовище-студент». 


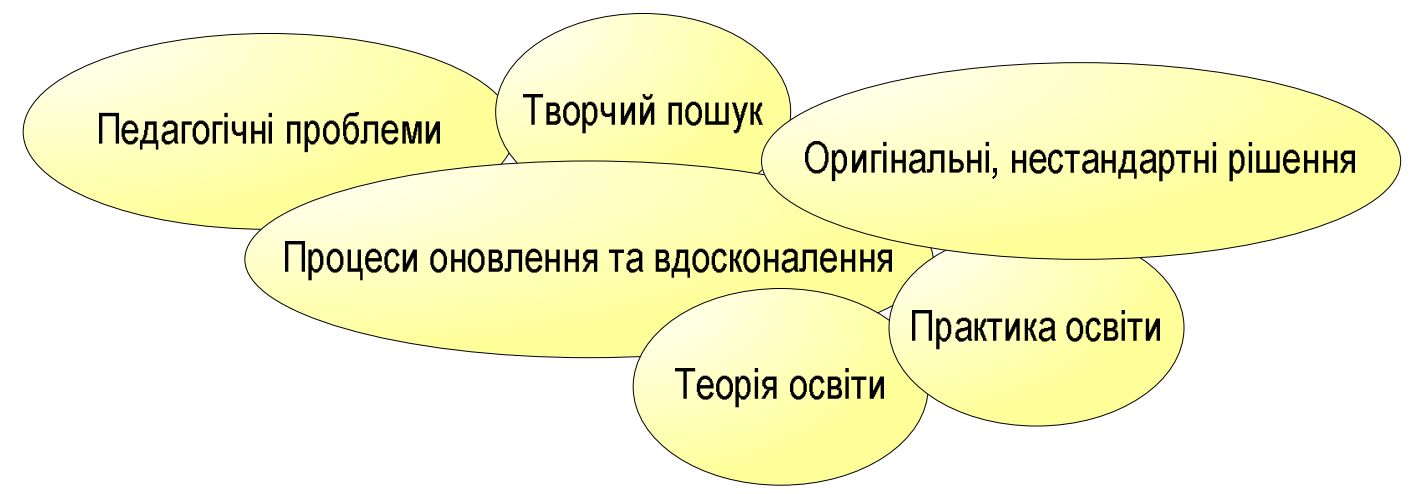

Рис. 1. Хмара «Інноваційні технології в освіті»

Згідно 3 [9] проблема інноваційного розвитку освіти і освітніх інновацій є актуальною, тому що вона викликає широкий суспільний і науковий резонанс. Інноваційна освітня діяльність передбачає розвиток творчого потенціалу педагогів і стосується не лише створення та поширення новизни, а і зміни у способі діяльності, стилі мислення учасників навчально-виховного процесу.

Сучасний фахівець має не просто досконало володіти знаннями, дотримуватися культури спілкування і культури поведінки, знати психологію поведінки, але і вміти критично мислити, бути гнучким, використовувати новітні комп'ютерні засоби, вміти знаходити найсучаснішу інформацію, що стосується конкретної сфери діяльності з метою подальшого практичного застосування. В умовах ринкових відносин важливо, щоб молода людина була не тільки підготовлена до майбутнього як знавець своєї спеціальності, а й розуміла загальнолюдську моральність, необхідність дотримання правил професійної етики.

Щоб навчити молодь нестандартно, творчо мислити, необхідні інноваційні підходи до викладання дисциплін, нестандартні методи і форми навчання - інтерактивні методи. Тому, в сучасних умовах поглиблення конкурентної боротьби на ринку праці, вивчення та використання інноваційних технологій навчання у системі освіти України є надзвичайно важливим.

Стан системи освіти сьогодні зумовлюється інфрормаційною революцією та зростанням обсягу знань, ускладненням і розширенням навчального матеріалу. Традиційні методики поступово втрачають свою ефективність, тому необхідно впроваджувати в навчальний процес сучасні педагогічні технології. В інноваційних технологіях закладені величезні можливості для підготовки компетентних і мобільних випускників, здатних успішно функціонувати в різних соціально-професійних спільнотах.

Сучасний ринок праці висуває до молодих фахівців нові вимоги ділової активності: це не тільки компетентність, професіоналізм, але і комунікабельність, ініціативність, відповідальність, самостійність, здатність пристосовуватися до складних ринкових умов [10].

Використання педагогічних технологій у навчальному процесі сприяє формуванню конкурентноздатного фрахівця. За визначенням В. Г. Кременя, «під педагогічною технологією слід розуміти вивчення, розробку й системне використання принципів організації навчального процесу на основі новітніх досягнень педагогіки, психології, теорії управління та менеджменту, інформатики, соціології тощо для розробки таких засобів навчання, що підвищують ефективність навчального процесу» [11].

Застосування інтерактивного навчання формує у студентів компетентність, розширює їх пізнавальні можливості в здобутті, аналізі та застосуванні інформації, а також $є$ базою формування умінь та навичок у майбутній професійній діяльності. Студенти навчаються ухвалювати важливі рішення, мають можливість спілкуватися та розвивати професійні вміння та навички. У них з'являється глибока внутрішня мотивація» [12]. Конфуцій писав: « Те, що я чую, я забуваю. Те, що я бачу й чую, я трохи пам'ятаю. Те, що я чую, бачу й обговорюю - я починаю розуміти. Коли я чую, бачу, обговорюю й роблю - я набуваю знань. Коли я передаю знання іншим, я стаю майстром». Ці слова є своєрідним поясненням інтерактивного навчання, з яким безпосередньо пов'язані педагогічні інновації.

Сучасне навчання студентів неможливе без використання інформаційно-комунікативних технологій, які дозволяють реалізувати диференційований підхід до студентів з різним рівнем готовності до навчання. Інформаційно-комунікативні технології - з одного боку, це потужний інструмент для 
отримання студентом найрізноманітнішої інформації, з іншого - ефективний засіб підвищення інтересу до навчання, а також мотивації, наочності, науковості тощо [13].

Сучасний студент вимушений обробляти великий обсяг інформації, тому вміння користуватись пошуковими системами, застосовувати принципи відбору та аналізу отриманої інформації являється первинним. Для покращення засвоєння поданої у межах навчального курсу інформації серед традиційних форм та методик викладання, все частіше використовуються інтерактивні методи.

Інтерактивні методи навчання є дієвим засобом впровадження нових освітніх технологій [14].

У роботі [15] зазначено, що стрімкий розвиток інноваційних технологій стає причиною освітніх ресрорм, які перетворюють освіту на продуктивний сектор економіки; а в Україні повинен забезпечуватися прискорений, інноваційний розвиток освіти шляхом оновлення змісту освіти та організації навчально-виховного процесу відповідно до демократичних цінностей, ринкових засад економіки, сучасних науково-технічних досягнень. На жаль, інноваційна діяльність у сфері освіти в Україні характеризується відсутністю цілісності та системності у розробці, обірунтуванні та освоєнні інновацій.

3 огляду на побудову суспільства на ґрунті ринкових відносин потреба у фахівцях економічної сфери завжди залишається актуальною. Вивчення економічних дисциплін з використанням інноваційних технологій, комп'ютерної техніки і новітньої інформації - один із способів оптимізації та урізноманітнення навчально-виховального процесу.

Особливого значення в процесі підготовки фрахівців економічної сфери набуває проблема формування комунікативної професійної компетентності як складової загальної професійної компетентності.

На сьогоднішній день важливим $є$ формування в сучасних фахівців економічної культури, що передбачає високий рівень фахової підготовки, дотримання законодавства України, правил професійної етики і норм загальнолюдської моралі. Економічна освіта молоді $є$ важливою складовою подальшого розвитку ринкових відносин в Україні. Студенти-економісти XXI ст. навчаються в період фрормування нової економіки інформаційного суспільства. Активне впровадження сучасних інформаційних технологій у життя людини призвело до розвитку інноваційних процесів і в освіті.

Метою роботи $є$ розробка методики формування професійної компетентності студентів економічних спеціальностей засобами інноваційних технологій

\section{II Матеріал і методи дослідження}

Вивчення публікацій та їх аналіз свідчить, що дослідженню проблем управління якістю освіти останнім часом приділяється достатньо уваги. Автори більшості публікацій найчастіше звертають увагу на реформування системи освіти, шляхом провадження інформаційних технологій та різноманітних інноваційних проектів, які мають підтримувати "технологічність" управління освітнім процесом і його якістю.

Деякі вчені відмічають важливі елементи індивідуалізації самостійної роботи студентів мотивація, візуалізація, раціональне поєднання різних технологій під час викладанні навчального матеріалу, наголошують на використанні телекомунікаційних мереж в сукупності з традиційними технологіями, що відкриває нові можливості, основними з яких є:розширення доступу до навчальнометодичної літератури, організація оперативної консультативної допомоги, розвиток бази для самоосвіти.

Згідно 3 [16], якість життя і освітній потенціал українського суспільства багато в чому визначається рівнем освіти і культури населення, його світоглядною орієнтацією і духовним розвитком, можливістю систематично отримувати і використовувати необхідну інформацію. Ці чинники впливають на ступінь включеності українського суспільства в національні і світові загальнолюдські процеси прогресивного розвитку. Освіта, що відповідає сучасним потребам суспільства і ринку праці, виступає могутнім адаптивним потенціалом у швидкоплинному трансформуючому суспільстві досучасних соціоекономічних реалій, що стає найважливішою умовою успішного і стійкого суспільного розвитку. 
Якість економічної освіти є багатогранною, визначальною категорією, яка характеризується складністю структури, внутрішніми і зовнішніми компонентами, потребує комплексного системного вивчення, фрормує сутність і різноманітні напрями досліджень.

Комплексне системне вивчення визначається тим, що:

1) процеси глобалізації вимагають високого рівня знань з іноземної (англійської як міжнародної) мови для ефективної співпраці на рівні: вітчизняне підприємство (організація) - закордонне підприємство (організація), а також з метою саморозвитку (самоосвіти) фрахівця шляхом одержання профресійно-значущої інфрормації з іншомовних джерел;

2) динамічний розвиток освіти різних країн пропонує значну кількість освітніх продуктів (навчальних програм, методичних комплексів, інформаційних освітніх технологій та ін.), що, у свою чергу, зумовлює необхідність їх більш ретельного аналізу та впровадження в навчальний процес;

3) комунікативна професійна компетентність студентів економічних спеціальностей не була глибоко досліджена і вимагає більш детального вивчення з точки зору її змістового наповнення, а також аналізу та добору ефективних технологій її формування.

Враховуючи актуальність зазначеної проблеми, ї̈ недостатню теоретичну розробленість і практичне упровадження, об'єктивну потребу і соціальну значущість, актуальним є питання формування професійної компетентності студентів економічних спеціальностей засобами інноваційних технологій.

Основним завданням досліджень, що проводяться $є$ розвиток творчих здібностей та уміння критично мислити студентів,

Розвиток здібностей, творчого, логічного мислення студентів реалізується як показано на рис. 2.

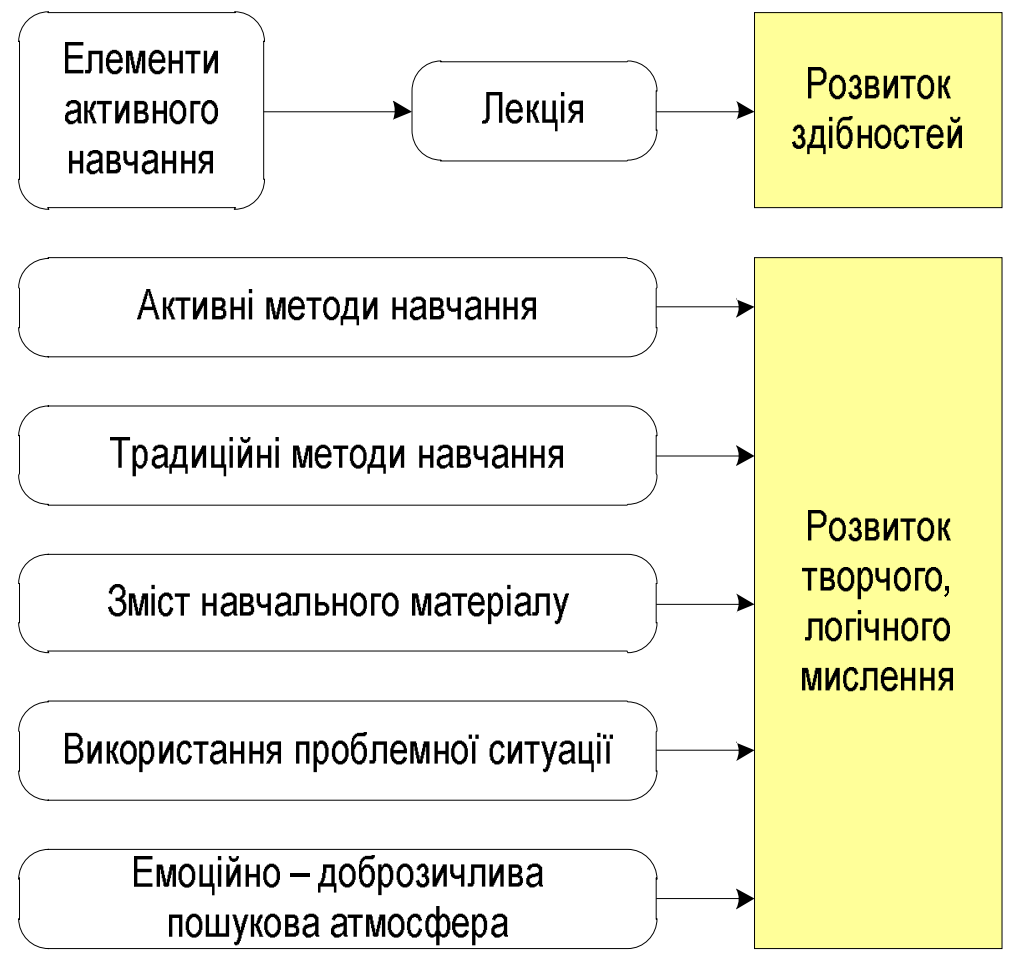

Рис. 2. Графр зв'язків розвитку здібностей студентів

Для впровадження будь-якої інновації потрібні затрати: час, людські ресурси, програмні засоби реалізації. Основним впровадником інноваційних методів $є$ викладач. Основною метою впровадження інноваційних методів $€$ активізація здібностей студента до навчання. При цьому слід враховувати, що кожний інноваційний підхід потребує доробки для застосування у конкретних умовах, що мають власну специфіку.

Завдання сучасної освіти не тільки дати студентам необхідні фрахові знання, але і творче мислення,що в жодній діяльності не виникає під тиском, тому важливим при проведенні навчальних занять з економічних дисциплін $€$ створення доброзичливого психологічного клімату, атмоссрери співпраці, які позитивного впливають на розвиток інтелектуальних здібностей майбутнього фахівця. 
Специфіка економічних предметів створює найбільш широкі можливості для цілеспрямованого формування не тільки практичних, але й інтелектуальних умінь для досягнення тих навчально-виховних цілей, які постають перед сучасною освітою [17].

\section{III Результати}

Під час викладання дисциплін застосовуються різні види інноваційних технологій, наведені на рис. 3.

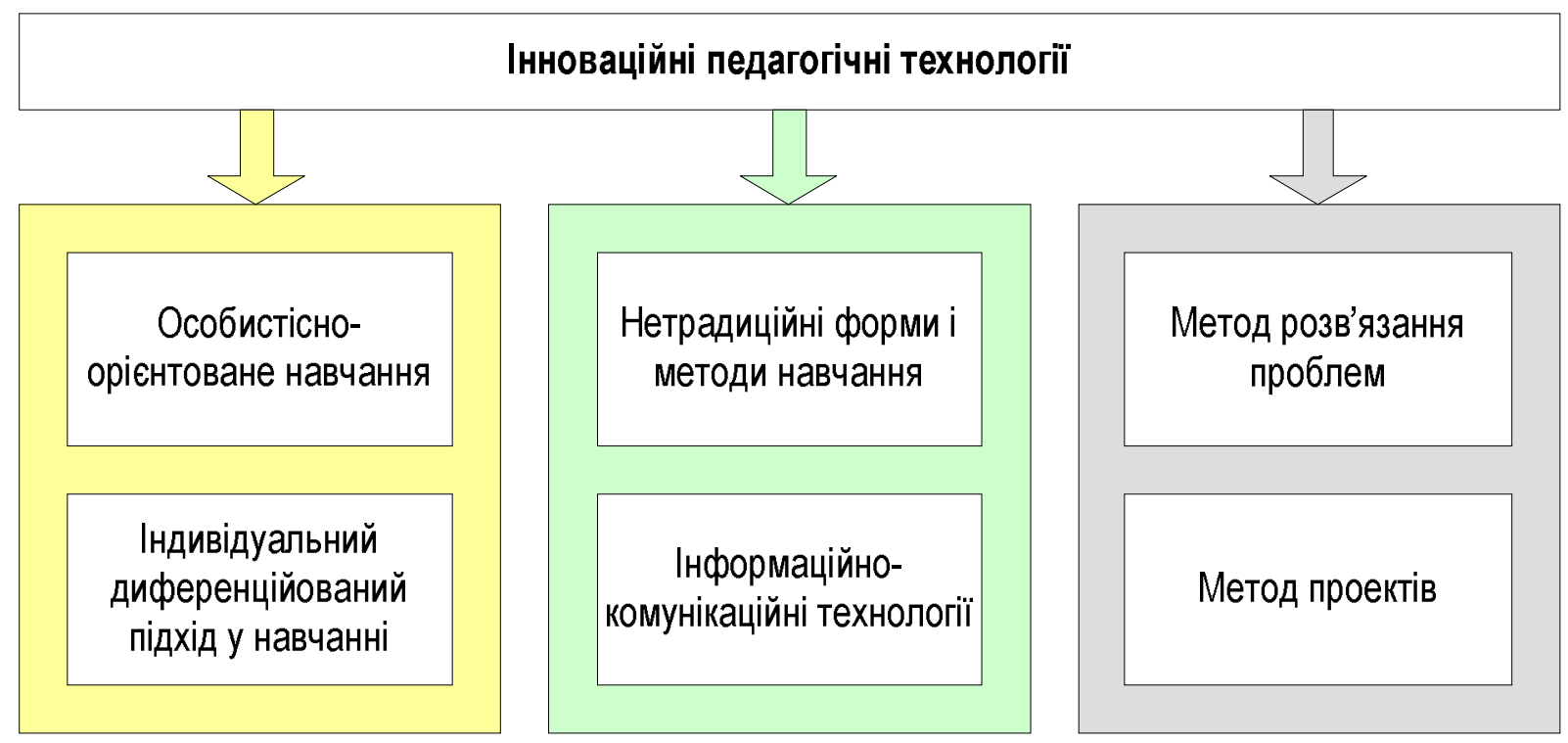

Рис. 3. Види інноваційних технологій

Розглянемо детальніше застосовні інноваційні технології.

Особистісно-орієнтоване навчання (ООН). При використанні ООН студенти вивчають наведені на рисунку 4 об'єкти, розвиваючі при цьому свої здібності.

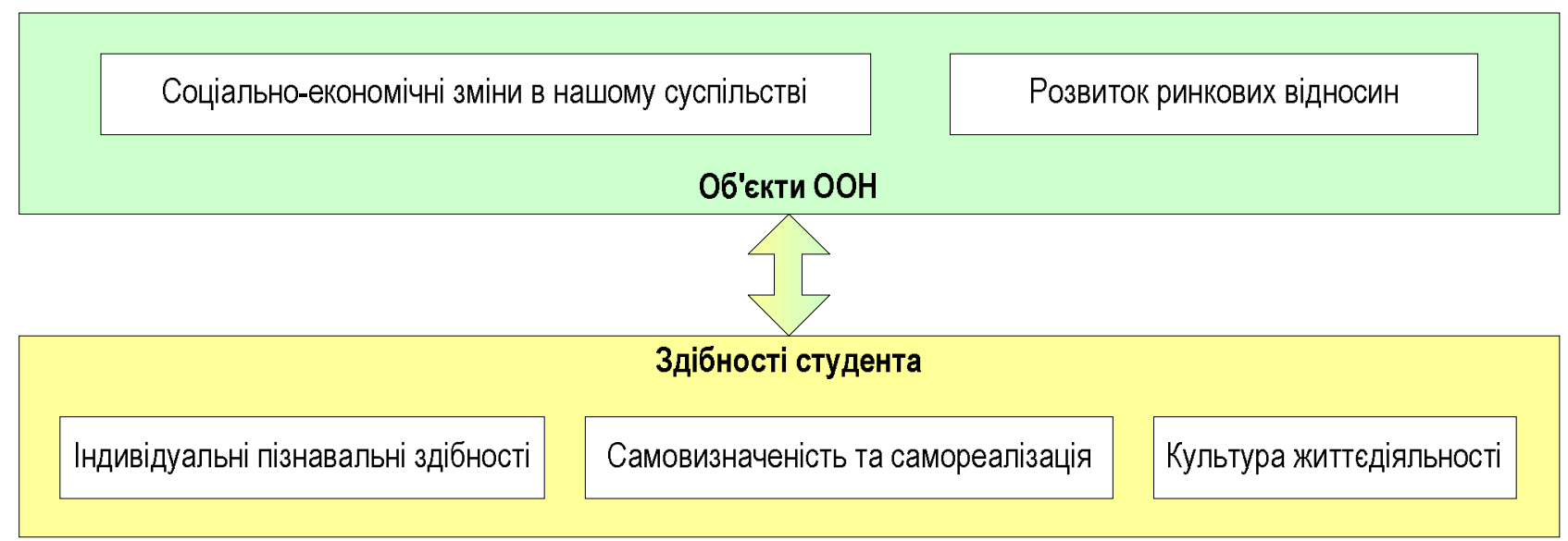

Рис. 4. Зв'язок між об'єктами ООН та здібностями студента

Індивідуальний диференційований підхід у навчанні (ДПН). Для певної групи студентів завжди притаманні деякі особливості, що вимагає використання диференціації навчання. Правильне застосування такої диференціації дозволяє стимулювати психічний розвиток студента. На рис. 5 наведені основні види індивідуалізації та диференціації навчання. 

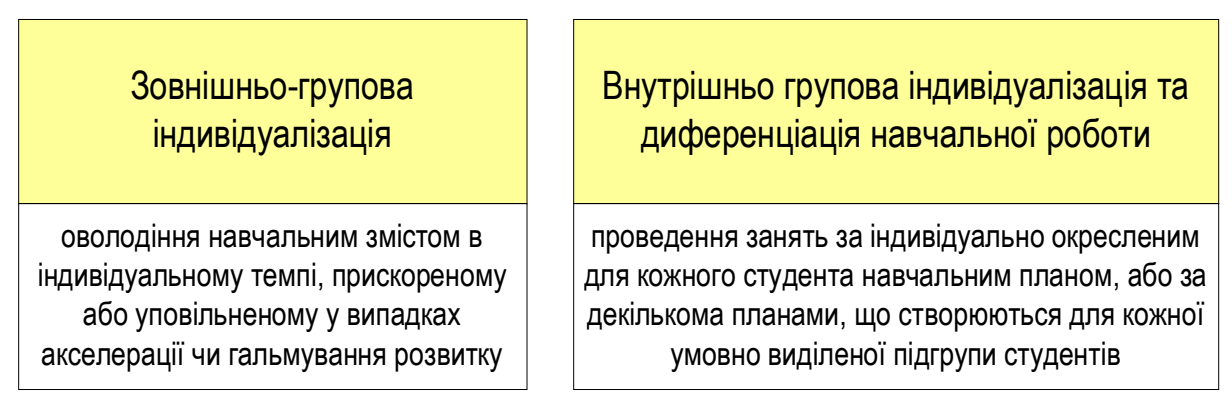

Індивідуалізація навчання у ході фрронтальних занять

застосування ефективних прийомів, які забезпечують урахування індивідуальних відмінностей кожної дитини

Рис. 5. Види диференціації навчання

Нетрадиційні форми і методи навчання (НФМН). НФМН можна розділити на форми, що застосовуються під час аудиторних занять, та поза аудиторні форми. Розглянемо застосування нетрадиційних форм проведення лекційних занять. Серед основних видів таких занять:

- проблемна лекція;

- лекція-діалог;

- лекція-конфреренція;

- відео-лекція.

Проблемна лекція представляє собою заняття організоване згідно зі схемою на рисунку 6.

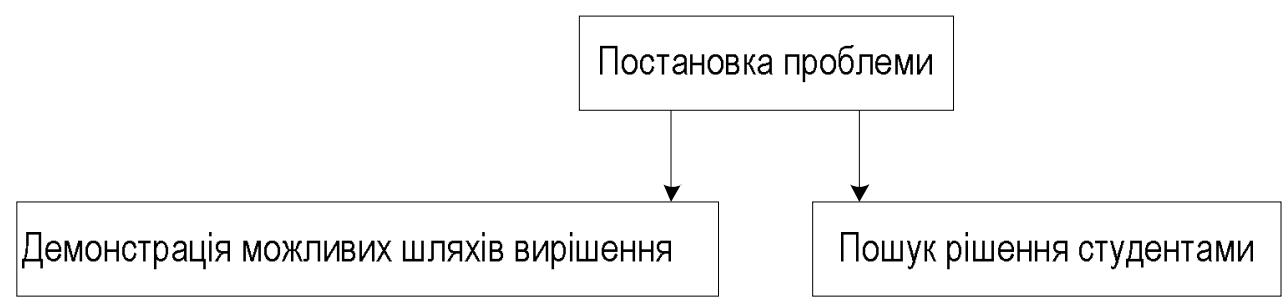

Рис. 6. Схема організації проблемної лекції

Демонстрація можливих шляхів вирішення проблемної ситуації допомагає студенту набути необхідних знань і досвіду, в той час як самостійний пошук рішення активізує їх творчі здібності. Звичайно можна комбінувати види вирішення проблемної ситуації. Алгоритм підготування проблемної лекції наведений на рисунку 7. Набуте в результаті вміння розв'язувати проблеми знадобиться студентам у повсякденному житті та збільшить їх цінність як професіоналів.

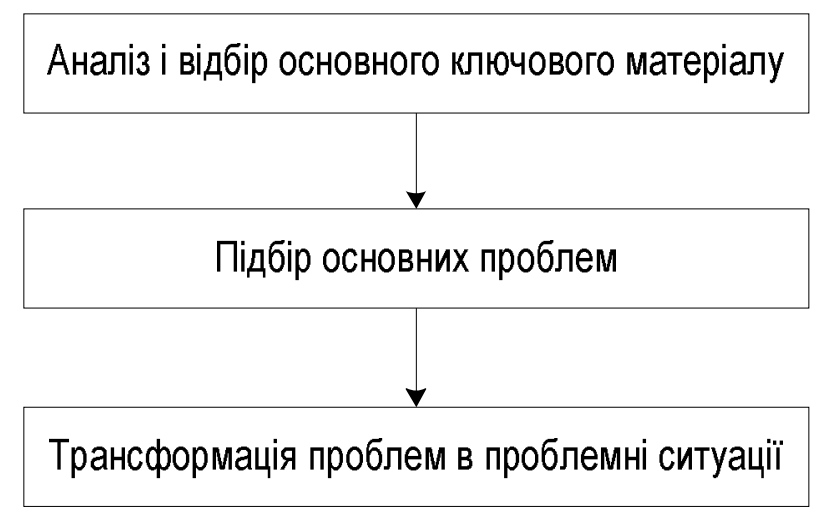

Рис. 7. Підготовка проблемної лекції

Лекція-діалог являється більш складною формою організації заняття, оскільки вимагає від викладача вміння правильно формувати діалог, направляти хід діалогу у необхідне русло. Порядок проведення лекції-діалогу наведений на рисунку 8. 


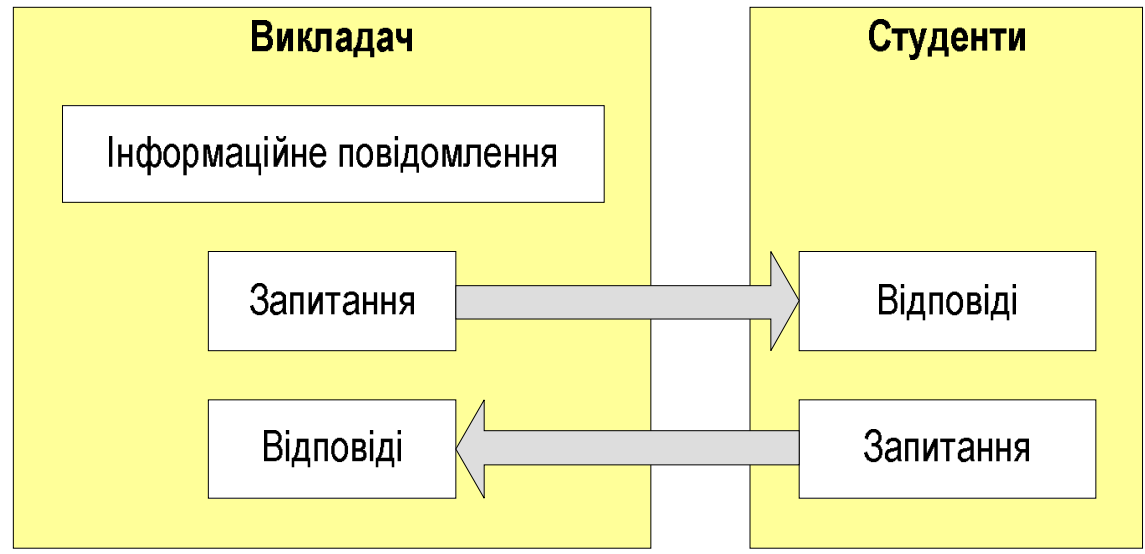

Рис. 8. Проведення лекції діалогу

Відповідно лекція-конфреренція є гібридом лекційного заняття і наукової конференції (рис. 9).

Складення плану лекції з чітко визначеними питаннями (план лекції)

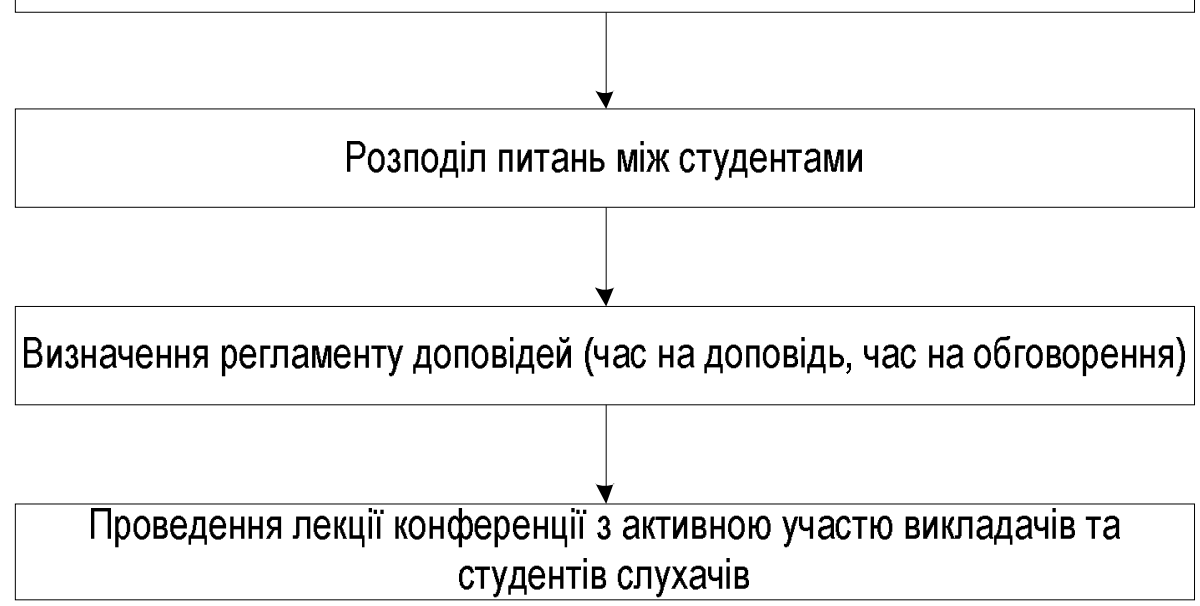

Рис. 9. Схема проведення лекції-конференції

Викладач може коментувати доповіді студентів, доповнювати. Студенти слухачі задавати запитання. Цей вид лекції активізує здатність студентів до самопідготовки, дозволяє виявити схильність студентів до педагогічної роботи.

Відео-лекція звичайно складається з перегляду відібраних викладачем матеріалів і допомагає студенту наочно осмислити поданий матеріал. Перегляд матеріалів слід супроводжувати коментарями викладача, обговоренням, студентам пропонується сфрормулювати висновки, узагальнення.

Працюючи над проблемою втілення інноваційних процесів в сучасну освіту, запропоновано під час проведення лекційних занять для студентів економічних спеціальностей використовувати сучасні інноваційні технології, які сприятимуть творчому мисленню молоді, вмінню самостійно знаходити відповіді на необхідні питання, систематизувати і узагальнювати матеріал, працюючи з навчальною літературою та сучасними комп'ютерними технологіями.

Згідно з [18] серед позааудиторних НФМН можна виділити види, наведені на рисунку 10.

Як зазначено вище (про проблемну лекцію) метод вирішення проблем, являється ефективним методом при викладанні економічних дисциплін. Основною задачею викладача при застосуванні цього методу є привиття студентам вмінь і навичок до аналізу проблемних ситуацій, логічного їх осмислення, методів і прийомів їх вирішення.

Проблемна ситуація на відміну від традиційних не має визначеного рішення, і задача студентів полягає у формуванні декількох шляхів розв'язання поставленої задачі, і виборі серед них оптимального. 


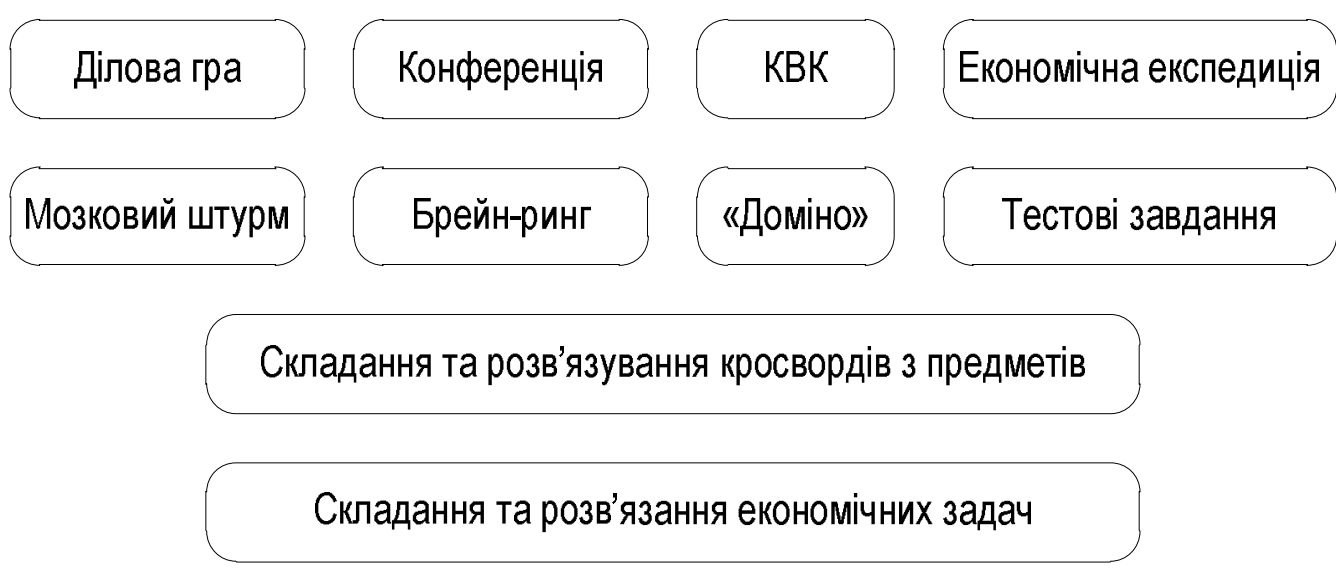

Рис. 10. Види позааудиторних НФМН

На основі суперечностей можна виділити ряд проблемних ситуацій, які наведені на рисунку 11.

Пошук шляхів використання наявних знань у нових умовах
Приклад: урок на тему «Попит, пропозиція, ринкова ціна». Після розгляду найголовніші економічні чинники (ціна одного товару, ціни інших товарів, доходи покупців, смаки на уподобання покупців, очікування покупців). Формування практичної задачі використання отриманих знань.

\section{Ситуації, в яких із різноманітних знань чи способів дії потрібно вибрати необхідні}

При вивченні економіки часто доводиться пояснювати навчальний матеріал, у якому стикаються судження «можливо-неможливо», «раціонально-нераціонально», «впливає на процес позитивно чи негативно» і ін.

Приклад: лекція на тему «Технологія створення підприємства», викладач ставить перед студентами проблемне запитання: «Як створити підприємство в умовах нестачі капіталу?»
Виникнення ускладнень під впливом «психологічного бар'єру» попереднього досвіду
Відома психологічна закономірність - вплив попереднього досвіду на процес засвоєння нових знань і способів дії, у науковій літературі зустрічається під назвами «психологічний бар'єр» попереднього досвіду, «явище інтерференції» і «явище від'ємного переносу». Студенти не можуть звільнитися від звичних способів дії й піти шляхом нових, оригінальних рішень. Це протиріччя - джерело створення проблемних ситуацій.

Рис. 11. Види проблемних ситуацій

Щоб створити проблемну ситуацію, треба поставити перед студентами таке практичне або теоретичне завдання, під час виконання якого вони відкривають для себе нові знання або способи дії.

Для більшої зацікавленості студентів у вивченні економічних дисциплін та їх самоосвіти використовують метод проектів [19], це педагогічна технологія, зорієнтована не на інтеграцію фактичних знань, а на їх застосування і набуття нових (часто шляхом самоосвіти). Німецький педагог А. Флітнер характеризує проектну діяльність як навчальний процес, в якому обов'язково беруть участь розум, серце і руки ("Lernen mit Kopf, Herz und Hand"), тобто осмислення самостійно добутої інформації здійснюється через призму особистого відношення до неї і оцінку результатів в кінцевому продукті.

За реаліями сьогодення будь-які з розглянутих інноваційних педагогічних технологій вимагають застосування інформаційно-комунікаційних технологій (IКT): наочність, яскравість та різноманіття донесення до студентів інформації засобами IКT доведене []. Особливості застосування IКТ для викладення економічних дисциплін це тема окремого дослідження. 


\section{IV Обговорення}

Описані вище методи, на думку автора, дозволяють ефективніше використовувати час навчального заняття, долаючи основні недоліки лекції, забезпечуючи активність, свідомість, міцність знань студентів. Адже такий вид роботи, як визначення ключових слів повідомлення, сприяє формуванню у студентів уміння виділяти в тексті головне, істотне, допомагає їм структурувати текст та схематично зважувати інформацію. Уміння їх визначити дозволяє швидко зорієнтуватися в матеріалі, відшукати та узагальнити необхідну інформацію. Правильно визначивши ключові слова тексту, які по суті $\epsilon$ "смисловими віхами" повідомлення, студент без утруднень може визначити концепт повідомлення, об'єднавши виділені слова в речення, яке буде слугувати відображенням смислової структури повідомлення. Неправильне виділення ключових слів $\epsilon$ свідченням нерозуміння опрацьованого матеріалу.

Заняття, які включають інноваційні фрорми їх проведення, сприяють не тільки систематизації і поглибленню теоретичних знань, але й залучають студентів до активної та творчої діяльності, розвивають уміння узагальнювати, відстоювати свою точку зору, закріплюють розуміння основних термінів і понять дисципліни. Водночас формується пізнавальний інтерес до дисципліни, студенти вчаться логічно мислити, розвивають творче мислення, інтуїцію, вміння працювати в команді.

Тому застосування інновацій в освітній системі $€$ удосконалення процесу навчання, полегшення сприйняття інформації, підвищення конкурентоспроможності випускників на ринку праці.

\section{V Висновки}

Головний вектор розвитку сучасної освіти визначається загальним спрямуванням на процес входження вітчизняної вищої школи до європейського та світового освітнього простору.

На підставі проведеного аналізу з урахуванням наукових досліджень та методичної літератури щодо впровадження інноваційних методів навчання у сучасній освіті визначено, що:

- пріоритетом національної концепції реформування і модернізації освіти $є$ створення інноваційного освітнього середовища у навчальних закладах через сприяння прогресивним нововведенням, в тому числі імплементації інноваційних методів навчання як складової частини формування навчального закладу інноваційного (підприємницького) типу;

- саме застосування широкого діапазону новітніх методів навчання стане однією з ознак інноваційних закладів і започаткує процес інтернаціоналізації сучасної освіти;

- у сучасній педагогіці має місце багатоваріантність інноваційних методів навчання, спрямованих на якісне засвоєння знань студентами, розвиток їх інтелектуальної діяльності, формування вмінь та навичок критичного осмислення професійної проблеми, здатності самостійно опрацьовувати інформацію, набуття якостей, що стануть у нагоді в майбутньому професійному житті;

- кожний навчальний заклад створює свою базу найбільш часто використовуваних інноваційних методів із врахуванням специфіки викладацького складу, контингенту студентів, особливостей спеціальностей, фахівців з яких готує конкретний вищій заклад, матеріально-технічного забезпечення та iн.

Таким чином, упровадження в навчальний процес сучасних педагогічних інноваційних та інформаційних технологій сприяють підготовці висококваліфікованих, конкурентноздатних фахівців. Перспективним у цьому плані вбачаємо дослідження застосування інформаційно-комунікативних технологій при вивченні економічних дисциплін, що сприяють швидкому засвоєнню матеріалу, формуванню фахової компетентності студентів, розвитку сучасного економічного мислення.

\section{Бібліографічні посилання}

1. Akbaba-Altun S. Information Technology Classrooms and Elementary School Principals' Roles: Turkish Experience. Education and Information Technologies, 2004, Volume 9, Issue 3, pp. 255-270.

2. Kalogiannakis M. A Virtual Learning Environment for the French Physics Teachers. Education and Information Technologies, 2004, volume 9, pp. 345-353.

3. Parker J. The Role of Information Communication Technologies in Enriching Adult Education Theory Building. Encyclopedia of Information Communication Technologies and Adult Education Integration, Columbia University, USA, 16 p. 
4. Collis B. Information Technologies for Education and Training. Handbook on Information Technologies for Education and Training, pp. 1-20.

5. Tatnall A. The various topics relating to education and information technologies. Education and Information Technologies, 2011, volume 16, pp. 225-226.

6. Dlamini, R., Nkambule F. Information and Communication Technologies' Pedagogical Affordances in Education. Encyclopedia of Education and Information Technologies, 2019, 14 p. DOl: https://doi.org/10.1007/978-3-319-60013-0_216-1

7. Bescherer C. Technologies in Mathematics Education. Encyclopedia of Education and Information Technologies, 2019, $14 \mathrm{p}$.

8. 10 Innovative Learning Strategies For Modern Pedagogy. URL https://www.teachthought.com/the-future-of-learning/10innovative-learning-strategies-for-modern-pedagogy/ (дата звернення 15.08.2019)

9. Вербило О. Ф. Теоретичні основи навчання економічних дисциплін. Київ: Вища школа, 2015. 167 с.

10. Мельникова О.В. Інновації у вищій освіті як чинник формування національної економіки знань. Харківського національного педагогічного університету імені Г.С. Сковороди «Економіка». 2014. № 14. С. 16-27.

11. Гай О. М. Інтерактивні методи викладання економічних дисциплін у вищих навчальних закладах в контексті забезпечення якості підготовки вітчизняних фахівців. Наукові праці Кіровоградського національного університету. Економічні науки. 2015. №. 27. С. 36-42.

12. Добридень А. В. Використання інноваційних технологій у практичній роботі сучасного педагога. Проблеми підготовки сучасного вчителя. 2012. № 6 (ч. 1). С. 107-112.

13. Паридуха О. Ю. Інноваційна технологія - невід'ємна складова освітнього процесу. Наук. зап. Вінниц. держ. пед. ун-ту ім. М. Коцюбинського. Серія: Педагогіка і психологія.№16. 2005. С. 101-103.

14. Барабась Д. Освітні інновації та їх імплементація в Україні. Науковий вісник Одеського національного економічного університету. 2016. № 3. С. 35-54.URL http://nbuv.gov.ua/UJRN/Nv_2016_3_5(дата звернення 20.09.2019)

15. Teaching Methods. URL: https://teach.com/what/ teachers-know/teaching-methods/ (дата звернення 27.08.2019).

16. Кремень В. Г. Дистанційна освіта - перспективний шлях розв'язання сучасних проблем професійної освіти. Вісник Академії дистанційної освіти. 2003. № 1. С. 4-11.

17. Сірий Є. В. Інноваційний розвиток освіти в Україні: розгортання проблеми та засадницькі орієнтири. Актуальні проблеми соціології, психології, педагогіки. Київ, 2010. С. 65-77.

18. Теслюк В. М., Якимовська А. В. Напрямки вдосконалення викладання економічних дисциплін. Научные труды SWorld. №. 2(43). T. 4. 2016. C. 15-20.

19. Романюк А. А. Використання інтерактивних технологій при викладанні економічних дисциплін. Збірник наукових праць Хмельницького інституту соціальних технологій Університету «Україна». 2010. № 2. С. 34-36.

20. Кінаш І.А. інформаційні технології в економічній освіті (Information technologies in economic education). Інформаційні технології в освіті, 2011, вип.10, с. 80-87.

\section{References}

1. Akbaba-Altun, S. (2004). Information Technology Classrooms and Elementary School Principals' Roles: Turkish Experience. Education and Information Technologies, 9(3), 255-270.

2. Kalogiannakis, M. A. (2004). Virtual Learning Environment for the French Physics Teachers. Education and Information Technologies, 9, 345-353.

3. Parker, J. (2018). The Role of Information Communication Technologies in Enriching Adult Education Theory Building. Encyclopedia of Information Communication Technologies and Adult Education Integration, Columbia University, USA, $16 \mathrm{p}$.

4. Collis, B. (2018). Information Technologies for Education and Training. Handbook on Information Technologies for Education and Training, 1-20.

5. Tatnall A. (2011). The various topics relating to education and information technologies. Education and Information Technologies, 16, 225-226.

6. Dlamini, R., Nkambule, F. (2019). Information and Communication Technologies' Pedagogical Affordances in Education. Encyclopedia of Education and Information Technologies, 14 p. DOI: https://doi.org/10.1007/978-3-319-60013-0_216-1

7. Bescherer, C. (2019). Technologies in Mathematics Education. Encyclopedia of Education and Information Technologies, $14 \mathrm{p}$.

8. 10 Innovative Learning Strategies For Modern Pedagogy. URL https://www.teachthought.com/the-future-of-learning/10innovative-learning-strategies-for-modern-pedagogy/ (accessed 15.08.2019)

9. Verbilo, O. F. (2015). Teoretichni osnovi navchannja ekonomichnih disciplin [Theoretical foundations of teaching economic disciplines]. Vishha shkola, Kiiiv, Ukraine, $167 \mathrm{p}$.

10. Melnikova, O. V. (2014). Innovatciï u vishchii osviti iak chinnik formuvannia natcionalnoï ekonomiki znan [Innovation in higher education as a factor in the formation of the national knowledge economy]. Kharkivskogo natcionalnogo pedagogichnogo universitetu imeni G.S. Skovorodi «Ekonomika», 14, 16-27.

11. Gai, O. M. (2015). Interaktivni metodi vikladannia ekonomichnikh distciplin u vishchikh navchalnikh zakladakh v konteksti zabezpechennia iakosti pidgotovki vitchiznianikh fakhivtciv [Interactive methods of teaching economic disciplines in higher education institutions in the context of ensuring the quality of training of domestic specialists]. Naukovi pratci Kirovogradskogo natcionalnogo universitetu. Ekonomichni nauki, 27, 36-42.

12. Dobriden, A. V. (2012). Vikoristannia innovatciinikh tekhnologii u praktichnii roboti suchasnogo pedagoga [The use of innovative technologies in the practical work of the modern teacher]. Problemi pidgotovki suchasnogo vchitelia, 6 (part 1), $107-112$. 
13. Paridukha, O. Iu. (2005). Innovatciina tekhnologiia - nevid'єmna skladova osvitnogo protcesu [Innovative technology is an integral part of the educational process]. Nauk. zap. Vinnitc. derzh. ped. un-tu im. M. Kotciubinskogo. Seriia: Pedagogika i psikhologiia, 16, 101-103.

14. Barabas, D. (2016). Osvitni innovatcii ta ïkh implementatciia v Ukraïni [Educational innovations and their implementation in Ukraine]. Naukovii visnik Odeskogo natcionalnogo ekonomichnogo universitetu, 3, 35-54. URL http://nbuv.gov.ua/UJRN/Nv_2016_3_5 (accessed 20.09.2019)

15. Teaching Methods. URL: https://teach.com/what/ teachers-know/teaching-methods/ (accessed 27.08.2019).

16. Kremen, V. G. (2003). Distantciina osvita - perspektivnii shliakh rozv'iazannia suchasnikh problem profesiinoï osviti [Distance education is a promising way of solving modern problems of vocational education]. Visnik Akademiï distantciinoï osviti, 1, 4-11.

17. Sirii, Ye. V. (2010). Innovatciinii rozvitok osviti v Ukraïni: rozgortannia problemi ta zasadnitcki orientiri [Innovative Development of Education in Ukraine: Deploying Problems and Background]. Aktualni problemi sotciologiï, psikhologiï, pedagogiki, 65-77.

18. Tesliuk, V. M., Yakymovska, A. V. (2016). Directions of improving the teaching of economic disciplines. SWorld Scientific Works, 2(43), T. 4, 15-20.

19. Romaniuk, A. A. (2010). Vikoristannia interaktivnikh tekhnologii pri vikladanni ekonomichnikh distciplin [Use of interactive technologies in teaching economic disciplines]. Zbirnik naukovikh pratc Khmelnitckogo institutu sotcialnikh tekhnologii Universitetu «Ukraïna», 2, 34-36.

20. Kinash, I.A. (2011). Information technologies in economic education. Information technology in education, 10, 80-87.

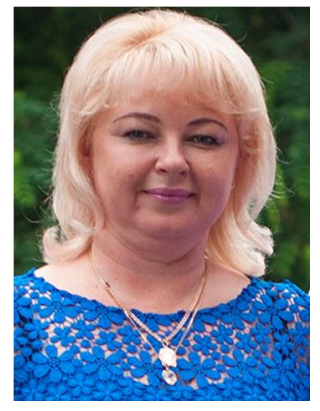

Дуба Ніна Павлівна.

Методист відділення, викладач економічних дисциплін,

Світловодський політехнічний коледж Центральноукраїнського національного технічного університету.

вул. Городоцька, 15, м. Світловодськ, Україна, 27501.

E-mail: nina_duba@ukr.net

\section{Duba Nina Pavlivna.}

Department Methodist, Lecturer in Economics,

Svitlovodsk Polytechnic College of the Central National Technical University, vul. Horodotska, 15, Svitlovodsk, Ukraine, 27501.

E-mail: nina_duba@ukr.net

\section{Citation (APA):}

Duba, N. (2019). Features of using of innovative pedagogical technologies during the training of economic specialties students. Engineering and Educational Technologies, 7 (4), 67-78. doi: https://doi.org/10.30929/2307-9770.2019.07.04.06

\section{Цитування (ДСТУ 8302:2015):}

Дуба Н. П. Особливості використання інноваційних педагогічних технологій під час навчання студентів економічних спеціальностей / Інженерні та освітні технологї. 2019. Т. 7. № 4. С. 67-78. doi: https://doi.org/10.30929/2307-9770.2019.07.04.06

Обсяг статmі: сторінок-12; умовних друк. аркушів- 1,738. 